\title{
Vinasse: current concepts, challenges and opportunities for the sustainability
}

\section{Vinaza: conceptos actuales, cambios y oportunidades para la sostenibilidad}

\author{
FERRARESI-DE ARAUJO, José Geraldo $\uparrow \&$ NIÑO-CASTILLO, Isaías Naú”** \\ Universidade Estadual do Sao Paulo (UNESP), Brazil. \\ "Centro Universitario CIFE, Mexico. \\ ID $1^{\text {st }}$ Author: José Geraldo, Ferraresi de Araujo / ORC ID: 0000-0002-2773-8641 \\ ID $1^{\text {st }}$ Co-author: Isaías Naú, Niño-Castillo / ORC ID: 0000-0003-0728-3798, CVU CONACYT ID: 919978
}

DOI: $10.35429 / E J R N .2021 .13 .7 .1 .9$

Received July 10, 2021; Accepted December 30, 2021

\begin{abstract}
The objective was to highlight the historical documents that foresee the use and abuse of ethanol production (vinasse) in Brazil according to literature published in the period 1934-2020. The methodology used was documentary, the review and analysis of which brought with it the synthesis and perspectives of vinasse as well as its uses and abuses. Results: a) there are legal instruments in Brzil since 1934 whose goal is to care for the environment; b) about in 1978 was prohibited the direct dumping of stillage into bodies of water and c) in 2011 environmental guidelines were provided on this topic to achieve sustainability in the Brazilian space. Conclusions: 1) as can be seen in the cited literature, vinasse is one of the most impressive respurces for ethanol production; 2) Brazil is the second largest ethanol producer worldwide; 3 ) the use of stillage for cooling sugarcane fiekds, its organic content, chemical and biochemical oxygen demand rates are high and 4) the synergy between academics from universities, the government sector, civil society, companies in the productive chain of the sugar energy sector, among others, is important.
\end{abstract}

\begin{abstract}
Resumen
El objetivo fue resaltar los documentos históricos que preveen el uso y abuso de la producción de etanol (vinasse) en Brasil de acuerdo con literaura publicada entre 19342020. La metodología empleada fue documental cuya revisión y análisis trajo consigo la síntesis y perspectivas de la vinaza así como sus usos y abusos. Resultados: a) existen instrumentos legales en Brasil desde 1934 que tienen como meta el cuidado del medio ambiente; b) desde 1978 se prohibió el vertido directo de la vinaza en cuerpos de agua y c) en 2011 se proveieron las directrices ambientales en este tópico para el logro de la sustentabilidad en el espacio brasileño. Conclusiones: 1) como se aprecia en la literatura citada, la vinaza es uno de los recursos más impactantes de la producción de etanol; 2) Brasil es el segundo productor de etanol a nivel mundial; 3) el uso de la vinaza para la refrigeración de los campos de caña de azúcar, su contenido orgánico, índices de demanda química y bioquímica de oxigeno son altos. y 4) es importante la sinergia entre académicos de universidades, sector gubernamental, sociedad civil, empresas de la cadena productiva del sector energético azucarero, entre otros.
\end{abstract}

Vinaza, Sostenibilidad, Brasil

\footnotetext{
* Correspondence to Author (Email: chay515@ hotmail.com)

$\dagger$ Researcher contributing first author.
} 


\section{Introduction}

It is estimated that biomass accounts for about $14 \%$ of all world primary energy consumption (National Electric Energy Agency, 2005). For this index is higher than that of coal and similar to that of natural gas and electricity. In developing countries, this share rises to $34 \%$, reaching $60 \%$ in Africa (Silva et al., 2005).

In Brazil, in 2014 sugarcane biomass accounted for $15.7 \%$ of the energy supply. Most of the energy from biomass is used in the production of ethanol. According to Union of the Sugarcane Industry (2014), the 2013/2014 harvest saw an increase of 3.68 billion liters in ethanol production, with the total reaching 25.04 billion liters versus 21.36 billion liters in the 2012/2013 harvest (Energy Research Company, 2014).

The replacement of gasoline by ethanol plus the replacement of diesel oil by bagasse in the sugarcane industry prevented the emission of 33.2 million tons of $\mathrm{CO}_{2}$ (Parsaee et. al., 2019). While a gasoline-only vehicle produces about $2.2 \mathrm{~kg} \mathrm{CO}_{2} /$ liter, an equivalent vehicle powered exclusively by ethanol emits about $1.3 \mathrm{~kg}$ $\mathrm{CO}_{2} /$ liter, or $59 \%$ of gasoline vehicle emission therefore the vinasse was succesfully used as sources of nutrients for biohydrogen (Bittencourt et al., 2014).

However, with the increase in ethanol production, the production of residues such as straw, filter cake, bagasse, wastewater and vinasse are proportionally increased. Specifically with regard to vinasse, it is characterized as an effluent from distilleries with high polluting power, about one hundred times greater than that of domestic sewage. This is due to its richness in organic matter, low $\mathrm{pH}$, high corrosivity, high levels of chemical oxygen demand (COD) and biochemical oxygen demand (BOD), high temperature at the end of the production process, and presents a high level of harm to the fauna and flora (Freire and Cortez, 2000 and Syaichurrozi et al., 2020).

The production of vinasse varies according to the different processes used in the production of ethanol. For each liter of ethanol, between 10 to 15 liters of vinasse are produced (Freire and Cortez, 2000). For every 1,000 $t$ of processed cane, an average of $360 \mathrm{~m}^{3}$ of vinasse is generated".
Considering the production of ethanol in Brazil, in the crop year 2013/2014, at around 25.04 billion liters, vinasse production was at least 250 billion liters (Szymanski, Balbinot and Nagel, 2010 and Belincanta, et al., 2016).

The literature on vinasse has been addressed mainly by the following researchers: Sheehan and Greenfield (1980), Willington and Marten (1982), Wilkie et al. (2000), Oliveira (2011) and Moares et al. (2015). The line of thought of these authors is convergent in the importance of the use of the waste, given organic matter content, as well as polluting capacity. Therefore, considering the high volume of vinasse production and its serious environmental impact, a review of the literature on vinasse, being the purpose of this study, is justified.

\section{Methodology}

The present investigation is exploratory, since it is characterized by a focus on the understanding of the facts (Lazarini, 1997). The exploratory research aims to provide a better understanding of the problem, in order to make it more explicit or to construct hypotheses and/or propositions. The vast majority of exploratory research involves a bibliographical survey and analysis of examples that stimulate understanding (Gil, 2007 and Meng, et al., 2020). Data collection was performed through a bibliographical survey in the search for information available in national and international publications (Fonseca, 2002).

For the construction of the theoretical framework, a bibliographic survey of articles was carried out in the databases of the Scientific Electronic Library Online; Web of Science; and theses and dissertations of the Integrated Library System of UNESP, UNICAMP and USP, using the keywords: vinasse, applications, and legislation on the subject.

\section{Results}

Vinasse is the sub product of the distillation of biomass for the production of ethanol, from sugar crops (beet and cane), starch crops (corn, wheat, rice and Manioc) and cellulosic material (crop residues, bagasse and wood). Vinasse stands out most in quantity and polluting capacity, being also known as stillage. This residue increases proportionally with the increase of ethanol production in the world (Moraes et al., 2015).

FERRARESI-DE ARAUJO, José Geraldo \& NIÑOCASTILLO, Isaías Naú. Vinasse: current concepts, challenges and opportunities for the sustainability. ECORFAN Journal-Republic of Nicaragua. 2021 
The quantitative composition of vinasse varies according to the time, maturation index, soil type and the raw material used for ethanol production (Rodrigues et al., 2012). Vinasse is characterized as distillery effluent with high polluting and fertilizing value; its polluting power, about one hundred times greater than that of domestic sewage, derives from its richness from organic matter. It is defined as a light brown liquid which darkens due to oxidation resulting from the fermentation process, its $\mathrm{pH}$ ranges from 3.7 to 5.0, it has high corrosivity and BOD and COD index, with a high temperature at the end of the production process (Freire and Cortez, 2000). Due to its high organic matter content, it assists in the proliferation of vectors of diseases and in its decomposition generates strong odor (Rafaldini et al., 2006).

Vinasse as an effluent composed of 93\% water and $7 \%$ solids; of these solids, about $75 \%$ are organic matter, formed of organic acids and, to a lesser extent, by cations such as $\mathrm{K}+\mathrm{Ca}+2$ and $\mathrm{Mg}+2$ and their alcoholic strength is not higher than $0.03{ }^{\circ} \mathrm{GL}$ (Araujo and Oliveira, 2020). Also, vinasse is the one with the highest pollutant content, with BOD varying from 20,000 to $35,000 \mathrm{mg} / \mathrm{L}$, where the amount discharged by the mills varies from 10 to 16 liters of vinasse per liter of ethanol depending on the production conditions and leaves the distillation apparatus on average between 85 to $90{ }^{\circ} \mathrm{C}$ (Silva et al., 2007 and Kasak \& Tor, 2020).

Regarding the composition of vinasse depends on factors such as: nature of the vinasse composition, fermentation system, type of yeast used, type of yeast treatment, additives used in fermentation, distillation apparatus, quality of the water used, the components used for disinfection, and the nature and composition of the raw material (Nogueira et al., 2015 and Nogueira \& De Oliveira, 2020).

Second generation ethanol vinasse has a higher organic matter content than first generation ethanol vinasse. However, the ratio of BOD and COD is comparable for both types. In contrast, the content of nutrients and minerals, especially potassium, is considerably lower for second generation vinasse. Thus, the application of this liquid into the soil cannot be justified, unlike the case of first-generation vinasse from ethanol production (Moraes et al., 2015).
In general lines, the chemical composition of the vinasse from different origins is summarized in Table 1.

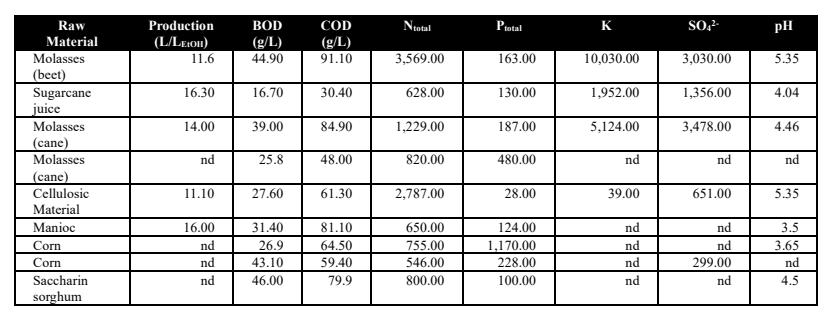

Table 1 Physical-chemical characteristics of vinasse of different raw materials

Source: Wilkie, Riedesel and Owens (2000) and Menezes (1980); $n d=$ no data available

By the late 1970s, increasing volumes of vinasse were being thrown into streams. The releases were of a seasonal nature, according to the ethanol production cycle, affecting selfregulation and self-reproduction of ecosystems (Corazza, 2006).

The impacts of the application of vinasse vary according to its chemical composition, volume and the periodicity of application. The high concentration of vinasse in soil and groundwater can lead to a high concentration of metals such as magnesium, aluminum, and iron, and also chloride and organic matter (Araujo et al., 2020).

Biorremediation is a technique for cleaning floors contaminated in a very practical way since use the same microorganisms that live in the ground and the subsoil (Irurbe, 2011 and Dias, et al., 2020).

In channels of vinasse flow, the contamination of the water table can reach $91.7 \%$, thus making the groundwater polluted. Once contaminated, the chances of reversal are small. For the author, vinasse presents a high level of harm to large aquatic animals, it drives away the Brazilian coastal marine fauna in the physiological phenomenon of spawning, and destroys microflora, microfauna, submerged and floating aquatic plants (Ludovice, 1997).

The indiscriminate application of vinasse into the soil intensifies salinization, metal leaching, greenhouse gas emissions and contamination of groundwater. 
The situation is more complex in the case of second generation ethanol vinasse and alcoholic beverage pentoses, for which there are no environmental standards, and cannot be used as fertilizer in sugarcane crops, unlike first generation ethanol vinasse (Moraes et al., 2015). Considering that in the 2013/2014 harvest Brazil produced, around 25.04 billion liters of ethanol, the production of vinasse in this harvest was at least 250 billion liters, a very worrying volume (Union of the Sugarcane Industry, 2014).

However, the inadequate and indiscriminate disposal of vinasse in soil, rivers, lakes and aquifers has received attention in Brazil since the 1930s, due to the environmental problems associated with this practice (Environmental Company of the State of São Paulo, 2006). Therefore, a series of legal frameworks have been constructed with the objective of minimizing and even eliminating the indiscriminate disposal of vinasse in soil, rivers, lakes and aquifers, and the main of which in Brazil and the world are highlighted below. Table 2 presents the legislation on effluent and vinasse disposal in Brazil.

\begin{tabular}{|l|l|}
\hline Legislation/Standard & \multicolumn{1}{c|}{ Content } \\
\hline Decree 8468/76: & $\begin{array}{l}\text { Approved the regulation of Law 997/76 } \\
\text { and its regulation on the "Prevention and } \\
\text { Control of Environmental Pollution", } \\
\text { referring to the discharge into watercourses } \\
\text { was restricted in the State of São Paulo } \\
\text { (SÃO PAULO, 1976) }\end{array}$ \\
\hline $\begin{array}{l}\text { Standard P4.331- } \\
\text { Resolution CONAMA }\end{array}$ & $\begin{array}{l}\text { Deals with the conditions and standards for } \\
\text { the discharge of effluents; complements } \\
\text { and alters Resolution No. 357 of March 17, } \\
\text { 2005, of the National Council for the } \\
\text { Environment CONAMA (BRAZIL, 2011) }\end{array}$ \\
\hline $\begin{array}{l}\text { Standard CETESB } \\
\text { P.4321 Vinasse }\end{array}$ & $\begin{array}{l}\text { Criteria and Procedures for Application } \\
\text { into Agricultural Soil, to establish the } \\
\text { criteria and procedures for the storage, } \\
\text { transportation and application of vinasse, } \\
\text { generated by the sugar-alcohol activity in } \\
\text { sugarcane processing, in the soil of the } \\
\text { State of São Paulo. Addresses the limits of } \\
\text { the application of vinasse, according to the } \\
\text { following parameters (CETESB, 2006). }\end{array}$ \\
\hline
\end{tabular}

Table 2 Legislation and rules on effluent and vinasse disposal in Brazil

Source: Adapted from Decree 8468/76, Standard P4.331 -Resolution CONAMA 430/11 and Standard CETESB P.4321 Vinasse

Point out from a history perspective, the main legal instruments referring to water protection and vinasse discharge.

Water Code (Decree 24.643 of July 10, 1934), which, among other things, safeguards water bodies against the disposal of pollutants;
- Law on environmental crimes (Law 9605, of February 12, 1998) in articles 33 and 54, indicates the penalties that will be imposed on offenders when the occurrence of death of animals due to the emission of effluents into the waters and in the occurrence of water pollution respectively, in which case the offenders receive imprisonment from one to three years or a fine, or both, cumulatively, for violation of article 33 and one to five years of imprisonment in violation of article 54;

- $\quad$ Decree of the Ministry of the Interior $n$. 323 of November 29, 1978, which states that from the 1979/1980 harvest, the direct or indirect discharge of vinasse into any water body by the alcohol distilleries installed or to be installed in the country is prohibited;

- Decree of the Ministry of the Interior n. 158 of November 3, 1980, which addresses its discharge into water bodies and on distillery effluents from sugar mills; Resolution of the CNRH Number 15 of $01 / 06 / 2001$, which gives the guidelines for the integrated management of surface, underground and meteoric waters;

- $\quad$ Law Number 7 960, dated 21/12/89, which provides for temporary detention for the crime of drinking water poisoning, among others;

Decree-Law Number 1413, dated $14 / 08 / 75$, which provides for the control of environmental pollution caused by industrial activities;

Decree of the Ministry of the Interior Number 124, dated 20/08/80, which lays down standards for the prevention of water pollution, for the localization of potentially polluing industries, constructions or structures, and for protection devices. 
Resolution of CONAMA Number 430, dated May 13, 2011, which provides for the classification of water bodies and environmental guidelines for their classification, and also establishes the conditions and standards for effluent releases and other measures. In accordance with $\S 4^{\circ}$, it establishes the conditions for effluent discharge, and in $\S 5^{\circ}$, which regulates effluent discharge standards, which are: $\mathrm{I}-\mathrm{pH}$ between 5 to 9 ; II temperature: less than $40^{\circ} \mathrm{C}$, where the temperature variation of the receiving body must not exceed $3^{\circ} \mathrm{C}$ in the mixing zone; III -sedimentable materials: up to 1 $\mathrm{mL} \mathrm{L-1} \mathrm{in} \mathrm{a} \mathrm{one} \mathrm{hour} \mathrm{test} \mathrm{in} \mathrm{an} \mathrm{Imhoff}$ cone. For discharge in lakes and ponds, whose circulation velocity is practically zero, sedimentable materials should be virtually absent; IV -discharge system with a maximum flow rate of up to $1 / 2$ times the average flow of the daily activity period of the pollutant, except in cases permitted by the competent authority: I oils and greases; II -mineral oils: up to 20 mg L-1; III -vegetable oils and animal fats: up to $50 \mathrm{mg} \mathrm{L}-1$ and VI -absence of floating materials.

The World Health Organization also created recommendations for wastewater reuse, the main one being:

Guidelines for the Safe Use of Wastewater, Excreta and Greywater-Volume IIWastewater Use in Agriculture: which presents a number of considerations regarding the use of wastewater in agriculture, seeking to benefit human health and the environment (WHO, 2006 and Kazak \& Tor, 2020).

In the United States, the Environment Protection Agency has established standards for wastewater reuse:

Guidelines for Water Reuse: which also provides for the reuse of wastewater in order to obtain benefits to human health and the environment (USEPA, 2004).
Despite all, the legal framework regarding the adequate use of vinasse in Brazil with regard to São Paulo Decree Law Number 8.468, September 8, 1976, it can be, considered superficial because it's prescribed only according to its potassium content. However, its potential associated environmental impacts weren't considered (Moares et al., 2015 and Aragao, et al., 2020).

However, the normative instruments and published legislation aim not only to mitigate the disposal of vinasse in soil and water bodies, but also to encourage new applications for this residue, with the assumption of promoting economic and social development in its reuse in consonance with environmental preservation. Simultaneously with the construction of these legal instruments, researchers have focused on finding uses and treatments for vinasse (Silva \& Gallo, 2021). According to Sheehan and Greenfield (1980), Willington and Marten (1982), Cortez et al. (1992), Oliveira (2011), Moares et al. (2015), based on technologies available for the reuse of vinasse, alternatives are listed in consonance with sustainable development, where the main products and processes from vinasse and their respective advantages and disadvantages are summarized in table 3 .

\begin{tabular}{|c|c|c|}
\hline $\begin{array}{c}\text { Process/Final } \\
\text { product }\end{array}$ & Advantages & Disadvantages \\
\hline $\begin{array}{l}\text { Anaerobic } \\
\text { Biodigestion }\end{array}$ & $\begin{array}{l}\text { Production of } \\
\text { electrical energy; } \\
\text { Reduction in BOD; } \\
\text { Effluent is a } \\
\text { fertilizer }\end{array}$ & $\begin{array}{l}\text { High cost; High } \\
\text { technology }\end{array}$ \\
\hline Fertirrigation & $\begin{array}{l}\text { Low cost; Easy to } \\
\text { adopt }\end{array}$ & $\begin{array}{l}\text { Unknown long term } \\
\text { effects; High logistic } \\
\text { cost }\end{array}$ \\
\hline Anaerosis & $\begin{array}{l}\text { Reduction in BOD } \\
\text { (70 to } 90 \% \text { in the } \\
\text { first process) and up } \\
\text { to } 99 \% \text { in the } \\
\text { second. }\end{array}$ & $\begin{array}{l}\text { Need of } \\
\text { construction, } \\
\text { maintenance and } \\
\text { monitoring of large } \\
\text { tanks or lagoon for } \\
\text { the treatment. }\end{array}$ \\
\hline Construction & $\begin{array}{l}\text { Significant } \\
\text { advances regarding } \\
\text { the resistance of the } \\
\text { material. } \\
\text { Potential for vinasse } \\
\text { discharge reduction }\end{array}$ & $\begin{array}{l}\text { Limited to } \\
\text { constructions near } \\
\text { the place of vinasse } \\
\text { origin. } \\
\text { High logistic cost }\end{array}$ \\
\hline Biodiesel & $\begin{array}{l}\text { Produce lipids with } \\
\text { higher added value } \\
\text { for biodiesel } \\
\text { production }\end{array}$ & In research phase \\
\hline Animal feed & $\begin{array}{l}\text { Cheap method; } \\
\text { Easy to adopt }\end{array}$ & $\begin{array}{l}\text { Not sufficiently } \\
\text { researched. }\end{array}$ \\
\hline Yeasts & $\begin{array}{l}\text { Reduction of } \\
\text { vinasse discharge }\end{array}$ & $\begin{array}{l}\text { High production } \\
\text { process cost }\end{array}$ \\
\hline
\end{tabular}

Table 3 Potential use of vinasse: advantages and disadvantages. Source: Adapted from Sheehan and Greenfield (1980), Willington and Marten (1982), Cortez, Magalhães and Happi (1992), Salomon (2007), Oliveira (2011), Moares, Zaiat and Bonomi (2015). 
In this case, of caring for the environment, the literature shoes a scenario characterized by many difficulties, for the construction and execution of a project that achieves sustainability through, ecological biofuel such as bioethanol with genuinely national capital (Vieira et al., 2018).

\section{Conclusions}

As reported in the literature cited in the theoretical reference of this article, vinasse is one of the most impacting residues of ethanol production, due to its polluting capacity as well as to the volume of its production, and with Brazil, being the second largest producer of ethanol in the world this volume is even more disturbing.

Although vinasse is to use for fertirrigation of sugarcane fields, its organic content, chemical and biochemical oxygen demand indexes are high, posing a potential risk for soil and water pollution with groundwater, rivers, streams, lakes (Ortíz, et al., 2017) and aquifers being significant (Niño-Gutiérrez \& Saldaña, 2012).

Given this reality, the government, both at federal and state levels, has developed a series of legal frameworks with the objective of restricting or even eliminating the indiscriminate dumping of vinasse, whether in soil or in water bodies. However, this is not enough if there is no real inspection, punishment and, above all, incentive for the use of vinasse for other purposes, with positive economic, social and environmental externalities.

However, it is this same substantial volume of organic content that gives vinasse the potential to be used for generating electric energy from anaerobic biodigesters. From the studies performed by researchers such as Sheehan and Greenfield (1980), Willington and Marten (1982), Oliveira (2011), Moares et al. (2015), the potential use of vinasse for anaerobic biodigestion, fertirrigation, anaerosis, and construction, as well as for the production of biodiesel, animal feed and yeast, has been shown.
However, there are no governmental incentive policies, no incentive for biogas or bioelectricy production at energy auctions in the regulated contracting environment, no financing of research and development of industrial scale biodigestors to produce electricity, and all of the other byproducts originating from vinasse (Parasee, et al., 2019).

Therefore, there is a need for synergy between universities, research centers, development agencies, development banks, multilateral institutions, companies in the sugar energy sector production chain, nongovernmental organizations, executive and legislative branches, both at the federal level and in the state spheres, to work together to curb the disposal of vinasse in disagreement with the law and, at the same time, encourage its reuse in line with the economic, environmental and social dimensions of sustainability.

\section{References}

Aragao, M.; Menezes, D. B.; Ramos, L. C.; Oliveira, H. S.; Bharagava, R. N.; Romanolo, L. F.; Teixeira, J. A.; Ruzene, D. \& Silva, D. P. (2020). Mycrorremediation of vinasse by Surface response methodology and preliminary studies in air-lift bioreactors. Chemosphere. 244, 125432. https://bit.ly/3z2oSge

Araujo, J. F. \& Oliveira, S.V.W.B. (2020). Energy and environmental analysis of vinasse processing using internal circulation biodigesters and concentrators for different production ranges of ethanol and its potential impact on Brazil. Environment, Development and Sustainable. https://doi.org/10.1007/s10668-020-00710-4

Araujo, J.F. et al. (2019). Economic Analysis of Internal Circulation Biodigesters and Vinasse Concentrators for the Generation of Electricity, Fertilizers, and Carbon Credits in Various Brazilian Economic Scenarios. Bioenergy. Research, 12(1), 1164-1186. https://doi.org/10.1007/s12155-019-10030-9

Belincanta, J., Alchorne, J. A., and Teixeira da Silva, M. (2016). The Brazilian experience with ethanol fuel: aspects of production, use, quality and distribution logistics. Brazilian Journal of Chemical Engineering, 33(4), 1091-1102. https://bit.ly/3cpe95L 
Bittencourt, E.; Larroche, C.; Novak, A. C.; Nouaille, R.; Sarma, S. J.; Brar, S. K.; Letti, L. A. J.; Soccol, V. T. \& Soccol, C. R. (2014). Economic process to produce biohydrogen and votatile fatty acids by a mixed culture using vinasse from sugarcane ethanol industry as nutrient source. Bioresource Technology. 154(1), 380-386. https://bit.ly/3g2bktU

Corazza, R. I. (2006). Impactos ambientais da vinhaça: controvérsias científicas e lock-in na fertirrigação. The Brazilian Society of Economy, Administration and Rural Sociology Congress (SOBER). Fortaleza, Brazil. http://www.sober.org.br/palestra/5/453.pdf/

Cortez, L. et al. (1992). Principais Subprodutos da Agroindústria Canavieira e Sua Valorização. Revista Brasileira de Energia, 2(2), 25-40. https://bit.ly/2S9AGgk

Environmental Company of the State of São Paulo. (2006). Vinhaça-Critérios $e$ procedimentos para aplicação no solo agrícola. https://bit.ly/3ioQOFh

Energy Research Company. (2014). Balanço Energético Nacional. https://bit.ly/3v3z7xA

Corazza, R. I. (2006). Impactos ambientais da vinhaça: controvérsias científicas e lock-in na fertirrigação. The Brazilian Society of Economy, Administration and Rural Sociology Congress (SOBER). Fortaleza, Brazil. http://www.sober.org.br/palestra/5/453.pdf/

Cortez, L., Magalhães, P. and Happy, J. (1992), Principais Subprodutos da Agroindústria Canavieira e Sua Valorização. Revista Brasileira de Energia, 2(2), 25-50. https://bit.ly/3x3cmv5

Dias, F. A.; Sander, S.; Albis, V. \& Guerra-Sá, R. (2020). Rhodotorula mucilaginosa Isolated from the Manganese Mine Gerais, Brazil: Potential Employment for Biorremediation of Contaminated Water. Water Air Soil Pollution (2020) 231:527. https://doi.org/10.1007/s.11270-020-04896-1

Environmental Company of the State of São Paulo. (2006). Vinhaça-Critérios $e$ procedimentos para aplicação no solo agrícola. https://bit.ly/3g0eGgJ

Energy Research Company. (2014). Balanço Energético Nacional. https://bit.ly/3fVLg3n
Fonseca, J. S. (2002). Metodologia da pesquisa científica. Fortaleza: UEC.

Freire, W. J. \& Cortez, A. B. (2000). Vinhaça de cana-de-açúcar. Guaíba: Agropecuária.

Gil, A. C. (2007). Como elaborar projetos de pesquisa. São Paulo: Atlas.

Iturbe, R. (2011). ¿Qué es la biorremediación? CDMX: UNAM.

Kasak, O. \& Tor, A. (2020). In situ preparation of magnetic hydrocar by co-hydrothermal treatment of waste vinasse with red mud and its adsorption property for $\mathrm{Pb}$ (II) in aqueous solution. Journal of Hazardous Materials. 393, 122391. https://bit.ly/3x4XFHW

Law Number 1.413. (August 14, 1975). Dispõe sobre o controle da poluição do meio ambiente provocada por atividades industriais. https://bit.ly/3iqmRoq

Law Number 7.960 (December 21, 1989). Dispõe sobre prisão temporária. https://bit.ly/3pt6EjL

Law Number 9.605. (February 12, 1998). Dispõe sobre as sanções penais e administrativas derivadas de condutas e atividades lesivas ao meio ambiente, e dá outras providências. https://bit.ly/3x4XM6k

Law Number 24.643. (July 10, 1934). Decreta $o$ Código de Águas. https://bit.ly/3cpMLoq

Lazzarini, S. G. (1997). Estudos de Caso para Fins de Pesquisa: Aplicabilidade e Limitações do Método. Farina et al. (Ed). Estudos de Caso em Agribusiness, Pioneira. São Paulo, Brazil. pp. 9-23.

Menezes, T. J. B. (1980). Etanol: o combustível do Brasil. Editora Agronômica Ceres, São Paulo, Brazil. https://bit.ly/3fYgxm9

Meng, L.; Jin, K.; Yi, R.; Chen, M.; Peng; J. \& Pan, Y. (2020). Enhancement of bioenergy recovery from agriculture wastes through recycling of cellulosic alcoholic fermentation vinasse for anaerobic co-digestion. Bioresource Technology. 311, 123511. https://bit.ly/3v5794t 
Moraes, B. S.; Zaiat, M. \& Bonomi, A. (2015). Anaerobic digestion of vinasse from sugarcane ethanol production in Brazil: Challenges and perspectives. Renewable and Sustainable Energy Reviews. 44(1), 888-903. https://doi.org/10.1016/j.rser.2015.01.023

National Electric Energy Agency. (2005). Atlas de energia elétrica do Brasil. https://bit.ly/34Xpnuk

Niño-Gutiérrez, N. S. \& Saldaña, J. (2012). Presa Revolución Mexicana de El Guineo en los albores del Siglo XXI. UAGro-Praxis. México.

Nogueira, C. E.; Melegari, S. N.; Micuanski, V. C. \& Lessa, R. (2015). Exploring possibilities of energy insertion from vinasse biogas in the energy matrix of Paraná State, Brazil. Renewable and Sustainable Energy Reviews. 48(1), 300-305. https://doi.org/10.1016/j.rser.2015.04.023

Nogueira, R. \& De Oliveira, S. (2020). Corrigendum to "Comparative exergy assessment of vinasse disposal alternatives: Concentration, anaerobic digestion and fertirrigation" [147, (1), 2020, 1969-1978)]. Renewable Energy. 156, 1395. https://bit.ly/3z8jZlL

Oliveira, M. (2011). Vinhaça alternativa: resíduo da produção de etanol pode ser usado para produzir biodiesel. Pesquisa FAPESP, No. 186, pp. 70-73. https://bit.ly/3ineGsK

Ordinance Number 124. (August 20, 1980). Estabelece normas para a localização de indústrias potencialmente poluidoras junto à coleções hídricas. https://bit.ly/3pBJB6j

Ordinance Number 158. (November 3, 1980). Mantém proibição de lançamento direto ou indireto de vinhoto em qualquer coleção hídrica. https://bit.ly/2TJT12t

Ordinance Number 323. (November 29, 1978). Proíbe o lançamento, direto ou indireto, do vinhoto em qualquer coleção hídrica, pelas destilarias do álcool. https://bit.ly/3cpxML8

Ortiz, F.; Niño-Gutiérrez, N. S.; González, J.; Villagómez, J. \& Torres, G. (2017). Diagnóstico físico-químico del agua en la laguna de Tres Palos, Guerrero, México. Tlamati, 8(2), 37-41. http://tlamati.uagro.mx
Parasee, M.; Kiani, M. \& Karimi, K. (2019). A review of biogas production from sugarcane vinasse. Biomass and Bioenergy. 122, 117-125. https://bit.ly/3isltl0

Rafaldini, M. E., Pissinatto, L. B., Manoel, R. M., Chagas, P. R. R. and Almeida, R. M. A. (2006). Controle biológico para sistema de vinhaça no solo. Engenharia Ambiental.3, No. 2, pp. 041-057. available at: https://bit.ly/3x91f41

Resolution CONAMA Number 430/2011. (2005). Dispõe sobre condições e padrões de lançamento de efluentes, complementa e altera a Resolução Numnber 357, de 17 de março de 2005, do Conselho Nacional do Meio AmbienteCONAMA. https://bit.ly/3g1sB6w

Rodrigues, A.; Ferreira, R.; Buzinaro, A.; Aparecido, H.; Inacio, L. \& Gasparin, E. (2012). Estimativa do potencial de geração de energia elétrica a partir da vinhaça. Acta Iguazu. 1(2), 80-93. https://bit.ly/3g1k3MK

São Paulo Decree Law Number 8.468, (September 8, 1976). Aprova o Regulamento da Lei $n .^{\circ}$ 997, de 31 de maio de 1976 que dispõe sobre a prevenção e o controle da poluição do meio ambiente. https://bit.ly/2RyCMG8

Sheehan, G. J. and Greenfield, P. F. (1980). Utilization, Treatment and Disposal of Distillery Wastewater. Water Research. 14(1), 257-277. https://doi.org/10.1016/0043-1354(80)90097-4

Silva, C. R. A. S., Garrafa, M. T. F., Navarenho, P. L., Gado, R. and Yoshima, S. (2005), A biomassa como energia alternativa para o Brasil. Revista Brasileira de Ciências Ambientais, 1(2), pp.1-12. https://bit.ly/34U7yMv

Silva, M. A. S.; Griebeler, N. \& Borges, L. (2007). Uso de vinhaça e impactos nas propriedades do solo e lençol freático. Revista Brasileira de Engenharia Agrícola e Ambiente. 11(1), 108-114. https://bit.ly/3x3Cp5n

Silva, J. V. \& Gallo, W. L. R. (2021). Potential impacts of vinasse biogás replacing fosil oil for power generation, natural gas, and increasing sugarcane energy in Brazil. Renewable and Sustainable Energy Review. 13 (1), 1-12. https://bit.ly/3w0FrHr 
Syaichurrozi, I.; Sarto, S.; Sediawan, W. \& Hidayat, M. (2020). Mechanistic model of electrocoagulation process for treating vinasse waste: Effect of initial $\mathrm{pH}$. Journal of Enviromental Chemical Engineering. 8(3), 103756. https://bit.ly/3x4i2Fj

Szymanski, M. S. E., Balbinot, R. \& Schirmer, W. N. (2010). Biodigestão anaeróbia da vinhaça: aproveitamento energético do biogás e obtenção de créditos de carbono-estudo de caso. Revista Semina. Ciências agrárias. 31(4), 901-912. https://bit.ly/3pt9lln

Union of the Sugarcane Industry. (2014). Revisão de estimativa da safra 2013/2014 no centro sul confirma crescimento de moagem direcionado para a produção de etanol. https://bit.ly/34WrTRv

U.S. Environmental Protection Ageny-USEPA. (2004). Guidelines for Water Reuse. https://bit.ly/2TN77BA

Vieira, E.; De Souza, A. \& Niño-Gutiérrez, N. S. (2018). Lecciones aprendidas de las políticas públicas experimentadas por Brasil 1928-2018. En Innovación, Tecnología y Educación. Retos y realidades. Ojeda, M. E.; Berrelleza, M. \& Bernal, B. E. (coords). Pp. 157-167. https://bit.ly/3cHOiXd

Willington, I. P. \& Marten, G. G. (1982). Options for handling stillage waste from sugarbased fuel ethanol production. Resources and Conservation. $\quad 8(1), \quad 111-29$. https://doi.org/10.1016/0166-3097(82)90036-0

Wilkie, A. C.; Riedesel, K. \& Owens, J. M. (2000). Stillage characterization and anaerobic treatment of ethanol stillage from conventional and cellulosic feedstocks. Biomass and Bioenergy. 19(1), 63-102. https://bit.ly/3ggyKKL

World Health Organization-WHO. (2006). Guidelines for the safe use of wastewater, excreta and greywater. https://bit.ly/3iqpoiq 